\title{
Pre-Translation Text Analysis as an Essential Step to an Effective Translation
}

\author{
Gayane Gasparyan \\ Yerevan Brusov State University \\ of Languages and Social Sciences
}

\begin{abstract}
Pre-translation text analysis is an integral part of an efficient translation procedure. In fact, it focuses on collecting intra-textual and extra-textual information on the text under translation. Collecting the intra-textual information is mainly based on a thorough analysis of the source text linguistic peculiarities, whereas the extra-textual information focuses basically on the communicative functional properties of both source and target texts. There exist different approaches towards this procedure and the stages of its accomplishment. Nonetheless, it should be noted that they all lead to a broader spectrum of discourse analysis with its intra-textual and extra-textual parameters and give birth to the translation-oriented pragmatic analysis before initiating translation process itself.

The article focuses on the interrelation and interaction of all the mentioned types of analysis (pragmatic analysis, discourse analysis, pre-translation analysis) as an essential requirement for a relevant translation.
\end{abstract}

Key words: intra-textual information, extra-textual information, source text, target text, translation oriented pragmatic analysis, discourse analysis, pretranslation analysis, intention, motivation, socio-cultural component.

\section{Introduction}

Pre-translation text analysis has always been considered an important procedure of an effective translation. There exist different approaches towards this procedure and the stages of its implementation. Some scholars focus on the 
analysis of the source text linguistic peculiarities and consider them within the examination of language media for effective translation. This approach is mostly employed by Russian translation researchers, who believe that complete understanding of source text message is the fundamental basis for adequate translation. Those who support this approach pay certain attention to the genre, vocabulary and syntactic peculiarities of the source text, which according to their viewpoint should be thoroughly examined to provide complete and valuable translation. R. Minyar-Beloruchev, A. Shvejtser, V. Komissarov, M. Brandes, V. Provotorov (Minyar-Beloruchev 1996, Shvejtser 1988, Komissarov 1990, 2002, Brandes, Provotorov 2001) and others take the view that the translation strategy may be better selected after detailed analysis of the source text linguistic peculiarities.

A number of scholars have developed different models of pre-translation analysis, which step by step describe the stages of its implementation. Among them the most fundamental and vividly developed is Christiane Nord's model (Nord 1991), which focuses basically on the communicative functional properties of both source and target texts. Much attention in this model is paid to the author's intention, which is defined from the point of view "of the sender who wants to achieve a certain purpose with that particular text. Yet, the best intentions do not guarantee a perfect result, particularly in cases where the situations of the sender and the receiver considerably differ. ... the receivers use the text with a certain function, depending on their own expectations, needs, previous knowledge and situational conditions" (Nord 2018:28). According to the author the same will happen with the translation where the sender of the message and the receiver are in different cultural and situational settings.

Yet, it should be noted that they all lead to a broader spectrum of discourse analysis with its intra-textual and extra-textual parameters and give birth to the translation-oriented pragmatic analysis before initiating the translation process itself. The article focuses on the interrelation and interaction of all the mentioned types of analysis (pragmatic analysis, discourse analysis, pretranslation analysis) as an essential requirement for a relevant translation. 


\section{Strategies and Steps of Pre-Translation Analysis}

The scholars, who consider the pre-translation text analysis as a necessary and essential part of a translation process, single out different steps for this procedure, which can be combined in the following groups: communicative, functional and linguistic (Ayupova 2014:213-216). Viewed from the perspective of collecting information necessary for an effective translation, the first group (communicative) includes a great deal of extra-textual information that can answer the following three questions: Where, When and Why. These are the questions, which automatically bring forth the relevant data about the place or culture in its wide sense, time or time-making characteristics of the period the text has been created in, the author with his/her intention and the recipient with his/her expectations and level of perception. As seen, the very first step to pre-translation analysis is collecting proper information around the source text to make the analysis complete and reliable. The information should contain relevant data about the author, mainly the culture, the country, the historical period and of course his intention and motivation. This information covers and responds the three mentioned questions: Where, When and Why, and includes the so-called extra-textual information.

The second step to pre-translation analysis is collecting required intratextual information concerning the genre with its linguistic peculiarities, the structure and the language media of the text under translation. Within this procedure a thorough analysis of the source text is highly required, as the translator should determine what and how to transmit into his newly created text (translation), keeping on the one hand the source text features, and making it readable and comprehensible by a new culture, on the other.

The first step to pre-translation analysis is based on socio-cultural relevance of reality reproduced by the source text, whereas the second one determines basically the language media relevance of the target text. Thus, both procedures are of great importance, as a professional translator has to deeply realize and signify whatever he/she is going to transfer to another mental system with its different way of perception and reconstruction of reality. Both types of analysis (extra-textual and intra-textual) may be effectively applied to 
any text of any genre. Though it should be noted that for the texts of different professional spheres (economy, finance, education, business, mass-media, IT, etc.) as well as official documents collecting both extra-textual and intra-textual information will be fast enough and easy. According to the first step of pretranslation analysis (extra-textual) the translator will easily manifest the information to answer the three required questions: Where, When and Why. According to the second step of pre-translation analysis (intra-textual) a good work with the terminology arsenal, the structure and syntax of the source text is actually enough.

Thus, if a text is not a piece of belles-letters or publicist style, the pretranslation analysis of the source text will not take much time to collect both extra- and intra-textual information. But if the text belongs to the mentioned two styles, the translator has a great deal of work to do with both source and target texts, to determine the socio-cultural and linguistic content of both textcreating sides. Hence, a piece of belles-letters or publicist style should be considered from the perspective of double-phase analysis: first the specification of all the details around the text, such as the author of the text, the author's intention, the message transfer method, where and when the text was created, the communicative purpose and the impact level on the expected recipient. All this background information on the source text will help the translator to easily understand the literary or publicist text/speech and to transfer its essence to a different substance for a different recipient. This is especially important while translating texts with a profound national substance, where the latter creates a specific quality of perceiving, reconstructing and reproducing the actual reality. The same mode scheme is observed in terms of perceiving the text by both the native recipient and the translated text reader, as the national mentality, national culture, national evaluation schema have their direct impact on both the perception of actual reality and the reinterpretation of different mental and ethic perspectives.

While speaking about these so very important issues concerning the initial stage of pre-translation analysis (collecting extra-textual information), one should keep in mind that it automatically gives way to the method of discourse 
analysis with its socio-cultural examination of extra-linguistic context of any utterance created in any situation and having a certain portion of the impact on the recipient. In this case another method of pragmatic analysis comes to be exercised to determine why and how the mentioned impact on the recipient is materialized in the utterance. The pragmatic analysis together with discourse analysis brings forth to the second stage of pre-translation analysis (collecting intra-textual information), as all the information existing around the text is anyhow materialized in the text by means of language media which is used by the author and determines his approach towards the utterance and its recipient. In any case, the methods of discourse and pragmatic analyses seem to be interdependent and inter-supplementary from the perspective of pretranslation analysis, which comes to cover research issues in both domains. As soon as the socio-cultural context is determined and the pragmatic value of the message is measured, the translator can be assumed to be ready to start the translation.

It should also be mentioned, that both discourse and pragmatic analyses are employed while collecting intra-textual analysis too. The discourse analysis of the language media and its certain impact on the recipient based on its pragmatic value come to answer the questions raised before: Where, When and Why, hence making the way to a perfect translation of the text proposed. If a translator is able to combine all the mentioned types of analysis of both extraand intra-textual information, he/she will have a high-quality product as a result.

\section{Pre-Translation Analysis in Political Discourse}

All of the above-mentioned can be considered in an example of political discourse. US ex-president Barack Obama's Statements on Armenian Remembrance Day on April 24, 2014 and April 22, 2016, which are very much like all his Statements on the occasion every year, are vivid samples for both extra- and intra-textual pre-translation analyses (the Statement on April 24, 2014 was translated into Russian and the Statement on April 22, 2016 was translated into Armenian). 
Thus, in order to be able to do an adequate translation, the translator according to the accepted procedure should collect proper socio-cultural information around the source text, containing relevant data about the author, the culture, the country, the historical period and his intention and motivation. In this particular situation for both Armenian and Russian translators there is no need to raise and analyze certain information about the author, his country and culture, as the latter is a rather well-known personality and much was written about him at different levels of political and international review. Nonetheless, if the translator is not an Armenian, he/she should examine the intra-textual reality, which is in fact an extra-textual one, to transform it correctly into another language. Besides the author's intention and motivation should be considered and thoroughly examined to detect why certain language means and structures come to express his certain approach towards whatever is employed in his speech.

The Armenian genocide is the subject of the President's Statement. Hence, the translator should collect information about this historical event, examine the details of mass destruction in Ottoman Turkey 1915 and repatriation of the Armenian population. Besides, the translator should be able to answer correctly the question: who the President's Statement is addressed to, since there are at least three real addressees who are to reconsider the events described by the speaker - the US people, the Armenian population of the USA and the Armenian people in general. The pragmatic impact on all these recipients is absolutely different. The US people are not always aware of the facts the President is speaking about. All the Armenian people, living anywhere, know and are very much concerned about them. The Russian speaking readers likewise the US people are not always aware of the facts described.

In his Statement the President as usual never uses the word genocide. Instead, he uses massacre, dark days, tragedy, violence, atrocity, painful elements, darkness of the past, horror and, what is mostly obscure and incomprehensible, Meds Yeghern, the Armenian equivalent to Great Genocide. Barack Obama is not the first and the only western politician, who does not use the word genocide, while speaking about the horrendous events of 1915. Many 
of them avoid uttering the term Armenian Genocide not to deteriorate relations with the Turkish government. Though all of them likewise Barack Obama evaluate the events anyhow as massacre, tragedy, violence, atrocity, etc. Nonetheless, none of them except the US President have ever used Meds Yeghern, a term, that can be conceived only by the Armenian people. Neither the Americans nor a representative of any other culture will be able to understand and be impressed by it. Both the illocutionary and perlocutionary effects will not be achieved by the speaker, if the addressee is non-Armenian. This is why, if the translator into Armenian keeps Utid Enting in the translation and is absolutely sure that it will have its certain impact on the reader, the translator into Russian will make the reader at least to guess, if he/she is really able to, the meaning of Мец Ехерн. This intra-textual piece of information, which makes the speech discourse open to the extra-textual reality, needs to be clarified by the translator (likewise by the author of the utterance for the US population) at least in footnotes or certain comments.

Another interesting fact concerning the translation of the Statement (April 22, 2016) title attracts attention. In English it sounds Statement by the President on Armenian Remembrance Day. In the Armenian translation it is accurately

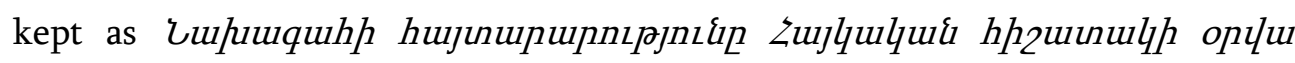
unhpny, where the only shift is made in the word Lujluulume that is written with a capital letter. Taking into consideration the fact that in English all the notional words in the title or words belonging to a national appurtenance are always written with a capital letter, the reader would never fix his/her attention to the capital letter in the word Armenian. In the Armenian translation only zujluuluis is written with a capital letter, whereas the whole combination zujlulqui hhzurnulp oplu could be capitalized. What is the translator's intention? Maybe to identify the certain national substance of the event? There are a lot of Remembrance Days celebrated in the USA, but for the US and other Armenian people it is a special day, therefore a certain spelling for Zujlquiquir.

The translator into Russian (April 24, 2014) has made a free translation of the title: Обращение президента США Б. Обамы ко Дню памяти жертв Геноцида армян. First, it should be mentioned, that Statement has been 
translated as Обращение, but not Заявление which leads to the conclusion, that it is an Address to the Armenian people, but not to the American population in general. In this case the use of Meds Yeghern/Мец Ехерн seems absolutely justified. The other element that is missing in the English version attracts attention: президента США Б. Обамы. In the English version the President is not given a name and the country is not specified. Why the translator into Russian found it necessary to mention the name of the president and the country he represents? Does it mean that he/she wishes to specify exactly which president of the country that has always been in trustworthy relationships with Turkey has made this certain statement? Or maybe, he/she tries to focus the reader's attention to the fact, that Barack Obama among all the other US presidents, was the first to make a statement of the kind? Who knows? Maybe.

Finally, the last element of the title, worth mentioning is памяти жертв Геноцида армян. In the English version the combination victims of Armenian Genocide is missing, whereas the translator into Russian seems to focus the reader's attention towards the fact, that the Armenian Remembrance Day is dedicated to the victims of the Armenian Genocide. Besides the use of Геноцид армян in the title forces the reader to determine for himself/herself the meaning of Мец Ехерн in the text. The modal value in both English Meds Yeghern and Russian Мец Ехерн undoubtedly acquire a higher level of significance (whereas neither massacre nor резня do). Nonetheless, one may arrive at a decisive conclusion, that both the English and Russian versions likewise the Armenian one are deliberately aimed at the Armenian audience. Though even if so, the translator should keep in mind that any reader of any other nationality, if he/she knows Russian, should be able to understand the message as well as an Armenian reader.

In the first paragraph of the Statement the President remarks: Today we solemnly reflect on the first mass atrocity of the 20th century - the Armenian Meds Yeghern - when one and a half million Armenian people were deported, massacred, and marched to their deaths in the final days of the Ottoman Empire. Likewise in the title, the translator into Armenian accurately keeps to 


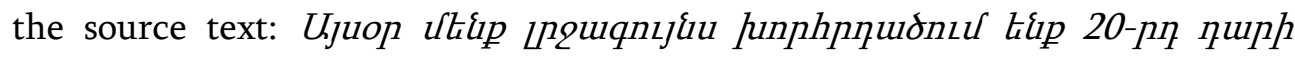

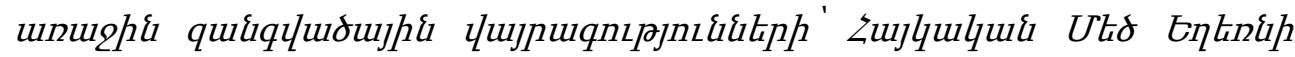

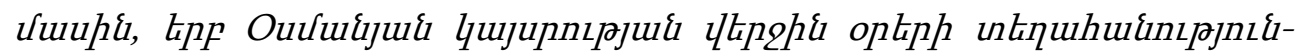

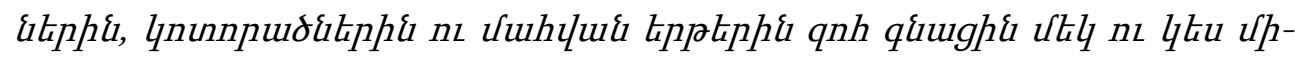
Lhni huulpp. The only modification that is found in the target text is the shift of Passive Voice in case of when one and a half million Armenian people were deported, massacred, and marched to their deaths into Active Voice tipp ...

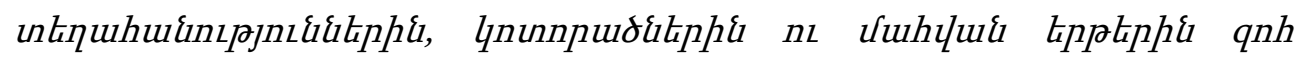
quughi Uth nu liku UhZhni hujkp. In the English version the grammatical form of Passive Voice focuses on the fact that the Armenian people were forced to undergo the terrible actions by someone, who is not mentioned in the speech. Taking into consideration, that Passive Voice is not so often and freely used in the Armenian language, the Armenian version seems to be reasonable.

The Russian translation of the Statement on April 24, 2014 provides a good deal of reinterpretation of the extract: Today we commemorate the Meds Yeghern and honor those who perished in one of the worst atrocities of the 20th century. We recall the horror of what happened ninety-nine years ago, when 1.5 million Armenians were massacred or marched to their deaths in the final days of the Ottoman Empire, and we grieve for the lives lost and the suffering endured by those men, women, and children. We are joined in solemn commemoration by millions in the United States and across the world. In so doing, we remind ourselves of our shared commitment to ensure that such dark chapters of human history are never again repeated. In Russian it sounds: Сегодня мы вспоминаем Мец Ехерн и чтим память тех, кто стал жертвой одних из самых страшных погромов 20 века. Мы вспоминаем тот ужас, который имел место 99 лет назад, когда в последние дни существования Османской империи были убиты 1,5 млн. армян. Мы скорбим о загубленных жизнях и страданиях, которые пережили эти мужчины, женщины и дети.

First, who perished is translated as стал жертвой, where becoming a victim if compared with perish is much stronger and significant. Then one of the worst atrocities of the 20th century is transferred into Russian as одних из самых 
страшньх погромов 20 века. The question is: why atrocity is translated as погром, why the worst is changed into одних из самыг страшных. The pragmatic value and the impact on the reader seems more effective in case of одних из самых страшньх погромов, as atrocity is just a crime against somebody, whereas погром includes more than manslaughter. Besides the worst does not sound so crushing as самые страшные (the most terrible).

Another very important technique device used by the translator into Russian gains the reader's attention: Мы вспоминаем тот ужас, который имел место 99 лет назад. In English 99 is written in letters ninety-nine years ago, whereas in Russian it is manifested in figures 99 лет назад. Again, and again a question arises, what it is done for. Again, and again the answer may be given by the translator mainly. We can guess only that this technique device is used by the translator to make the numeral message more vivid and functional.

The last paragraph of the Statement has also undergone certain reinterpretation by the translator into Russian: Today, our thoughts and prayers are with Armenians everywhere, as we recall the horror of the Meds Yeghern, honor the memory of those lost, and reaffirm our enduring commitment to the people of Armenia and to the principle that such atrocities must always be remembered if we are to prevent them from occurring ever again. The Russian version provides quite a new vision of the presidential commitment: Сегодня наши мысли и мольбы повсюду адресованы армянам, мы помним ужас Мец Ехерна, чтим память погибших и подтверждаем взятое на себя обязательство содействовать армянскому народу и принципу предотвращения повтора подобных зверств в будущем.

In fact, ... we stand with the Armenian people throughout the world ... is substituted by наши мысли и мольбы повсюду адресованы армянам, which does not absolutely mean that the USA support the Armenian people throughout the world. It rather shows how concerned and interested the USA President is about the Armenian matter and its further solution. In the original ... чтим память погибших ... and ... и принципу предотвращения повтора подобных зверств в будущем ... are also missing. This part of the translation rather comes to prove the beginning of the sentence that the USA are very 
much concerned to prevent repetition of similar atrocities in the future, but not their ongoing commitment to a democratic, peaceful, and prosperous Armenia. In fact, the perlocutionary effect of the message in this sentence of the translated version is achieved by such language means as чтим память погибших and подобныге зверства, which determine the translator's modal evaluation of the facts the President touches upon in his Statement. A rather free translation, isn't it? As seen, the translator is very much concerned to transfer to the target language his/her own vision of the President's approach towards Meds Yeghern/Armenian Genocide on Armenian Remembrance Day. It also means that the translator has done a good deal of work before starting the translation. He has examined thoroughly the socio-cultural context around the text on the facts he/she was going to transfer to his/her native cultural domain and has measured the recipient's scope to perceive, reconstruct and reconsider this context in a certain situation.

\section{Conclusion}

To conclude, one can confidently assert that the extra- and intra-textual sociocultural/discourse and translation oriented pragmatic analysis of both source and target texts become an integral procedure of pre-translation analysis to have an effective product as a result. They all are basically interwoven within the course of pre-translation analysis becoming interrelated and interdependent by their nature.

\section{References:}

1. Ayupova, R. (2014) Pretranslation Text Analysis as a Part of Translation Process, ScienceDirect, Procedia-Social and Behavioral Sciences 136, Published by Elsevier Ltd. Available at: <http://creativecommons.org/bync-nd/3.0/> [Accessed June 2019].

2. Brandes, M.; Provotorov V. (2001) Predperevodcheskiy analiz teksta. M.: NVI tezaurus.

3. Komissarov, V. (1990) Teoriya perevoda (Lingvisticheskie aspekti). M.: Visshaja shkola. 
4. Komissarov, V. (2002) Sovremennoe perevodovedeniye. M.: ETS.

5. Minyar-Beloruchev, R. (1996) Teoriya i metodi perevoda. M.: Moskovskiy Licey.

6. Nord, C.; Sparrow, P. (1991) Text Analysis in Translation: Theory, Methodology and Didactic Application of a Model for TranslationOriented Text Analysis. Amsterdam-New York: Amsterdam/Atlanta, GA Rodopi.

7. Nord, C. (2018) Translating as a Purposeful Activity. London/New York: Routledge.

8. Shvejtser, A. (1988) Teoriya perevoda (status, problemi, aspecti). M.: Nauka.

\section{Sources of Data:}

1. Barack Obama's Statement on Armenian Remembrance Day on April 24, 2014. Available at:

<http://obamawhitehouse.arcives.gov/.../2014/.../24/statement-presidentarmenian-remembrance-day> [Accessed June 2019].

2. Russian translation of Obama's Statement on Armenian Remembrance Day on April 24, 2014. Available at:

<https:/www.panorama.am/ru/world/2014/04/24/obama-statement> [Accessed June 2019].

3. Barack Obama's Statement on Armenian Remembrance Day on April 22, 2016. Available at:

<https://obamawhitehouse.arcives.gov/.../2016/.../22/statement-presidentarmenian-remembrance-day $>$ [Accessed June 2019].

4. Armenian translation of Obama's Statement on Armenian Remembrance Day on April 22, 2016. Available at: <https://usembassy.gov>Home $>$ News and Events-HY> [Accessed June 2019]. 


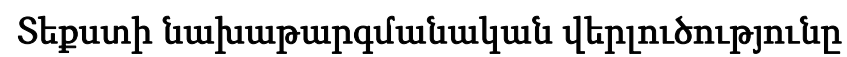

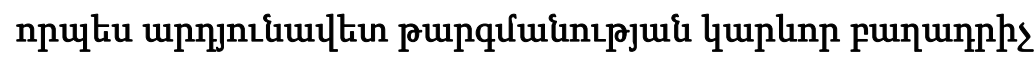

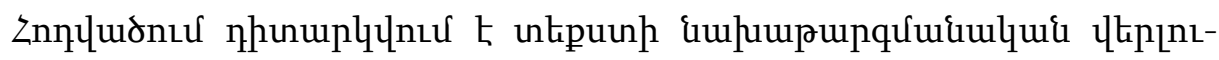

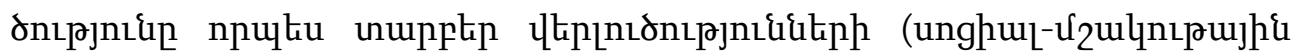

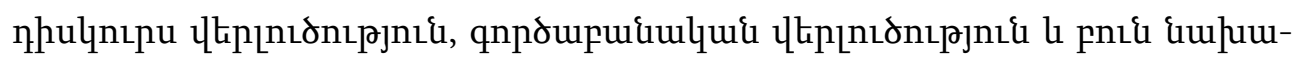

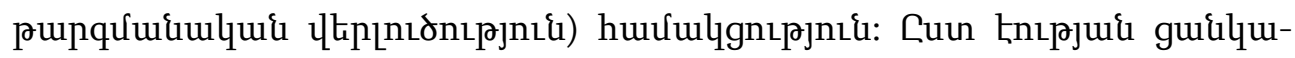

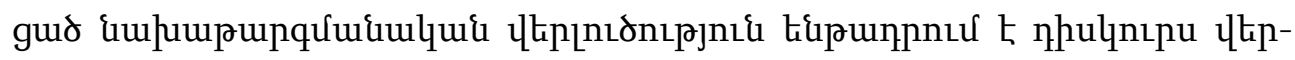

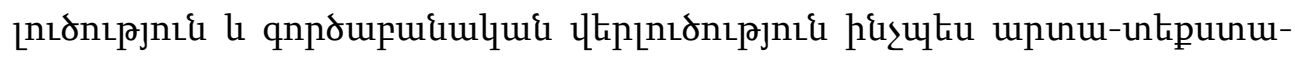

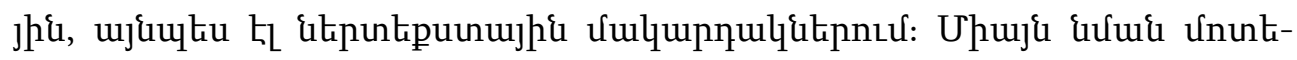

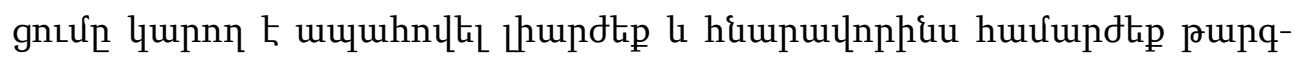
ưuinıpjnı\{:

Received by the Editorial Board 08.09.2019

Recommended for publication by the reviewers 10.10.2019

Accepted for print 15.01.2020 